\title{
SLC6A3 Gene
}

National Cancer Institute

\section{Source}

National Cancer Institute. SLC6A3 Gene. NCI Thesaurus. Code C113524.

This gene plays a role in dopamine uptake. 